\title{
Pärke, Parks and Reservate - biosphere reserves in Austria, Germany and Switzer- land on their way towards Biosphere 4.0?
}

\author{
Michael Jungmeier, Axel Borsdorf, Valerie Braun, Volker Häring, Thomas Hammer \& Christina Pichler- \\ Koban \\ Contributing authors: Peter Annighöfer, Arne Arnberger, Monika Auinger, Julia Falkner, Flurin Filli, Michael Huber, Hubert \\ Job, Lukas Kindl, Christine Klenovec, Rebecca Knoth, Günter Köck, Werner Konold, Armin Kratzer, Lutz Möller, Ingo \\ Mose, Franz Rauch, Peter A. Rumpolt, Thomas Scheurer, Annette Schmid Hofer, Eike von Lindern, Astrid Wallner, Norbert \\ Weixlbaumer, Lisa Wolf, Stefan Zerbe \& Daniel Zollner
}

Keywords: UNESCO MAB-Programme, biosphere reserve, governance, sustainability, Austria, Germany, Switzerland

\section{Abstract}

The biosphere reserve (BR), as conceived by UNESCO, is a permanent intervention towards sustainable development. With 727 BRs in 131 countries (Österreichisches MAB-Nationalkomitee 2021), this means interventions in highly diverse environmental, economic, socio-cultural and institutional contexts. With the MAB Strategy 2015-2025, the Lima Declaration 2016 and the Lima Action Plan 2016-2025, UNESCO BRs should develop fully into model regions for the implementation of the Sustainable Development Goals 2015-2030 (SDGs) (United Nations 2015). Because of their varied contexts, the UNESCO World Network of Biosphere Reserves consists of different, but globally self-similar, fractal institutions.

In this article we emphasize the understanding, implementation and management of BRs in Germany, Austria and Switzerland. These three European democracies are examples of federally structured states with comparatively wealthy economies as well as high political stability. Respect for property rights, regional acceptance, decentralized decisionmaking, and micro- and macro-economic considerations have always played decisive roles in the development of BRs in the DACH countries. We aim to identify, analyse and discuss the distinct characteristics and peculiarities of BRs in this area. We investigate how the framework conditions of sustainability, as presented in the concept of BRs, are perceived, discussed and implemented.

As a basis for our analysis, we use a sample of 18 peer-reviewed publications, which were published collectively as a book on BRs in the DACH countries (Borsdorf et al. 2020). The individual publications present overviews, case studies and in-depth investigations in the three countries. All authors were invited to participate in a meta-text analysis. This was conducted in the form of a survey, a transdisciplinary workshop with a reflective design using a virtual whiteboard, and a concluding feedback loop. The results of the qualitative exploration are interpreted against the background of international comparisons and recent scholarly discussions. Based on the assumption that different types of ambiguities and conflicts are inherently a key element of the BR concept, we conclude that the DACH countries may have found specific ways to deal with and overcome these differences.

\section{Introduction}

Biosphere reserves in Germany, Austria and Switzerland in a global context

The biosphere reserves (BRs) of the UNESCO World Network of Biosphere Reserves (WNBR) can be seen as learning sites in which innovative approaches for sustainable development are implemented in cooperation with various stakeholders and their specific ecological, economic and social interests. After the introduction of the MAB programme in 1970 / 1971, the establishment of the WNBR in 1976, a fundamental adaptation of the programme in 1995 (Seville Strategy) and the Madrid Action Plan in 2005, the concept underwent a further major revision with the Lima Action Plan in 2016. The main innovation was the consistent orientation of the BR concept towards the UN goals for global sustainable development (Sustainable Development Goals [SDGs]) (see Figure 4; see also UNESCO 1996, 2009, 2015a, 2015b, 2016a, 2016b; United Nations 2015).
Germany currently has 16, Austria four and Switzerland two UNESCO-designated BRs, see Figure 1. Zonation of BRs is crucial in conceptualizing their conservation functions. Therefore, all BRs must have a zoning plan (core area, buffer zone and transition area; see Braun et al. 2020).

Biosphere reserves and the changing conceptions of sustainability

The term sustainability is subject to constant changes of meaning (see Grober 2010), as seen in Figure 2. In the DACH (acronym for Deutschland (Germany, Austria and Confoederation Helvetica (Switzerland)) countries, the concept of sustainability has existed since the Middle Ages, although it was limited to individual natural resources: early forest and pasture regulations in the Alpine region allowed the long-term use of the corresponding resources. Sustainability in the sense of the sustainable use of renewable natural resources is often attributed to Hans Carl von Carlowitz and his book Sylvicultura Oeconomica (Carlowitz 1713). 


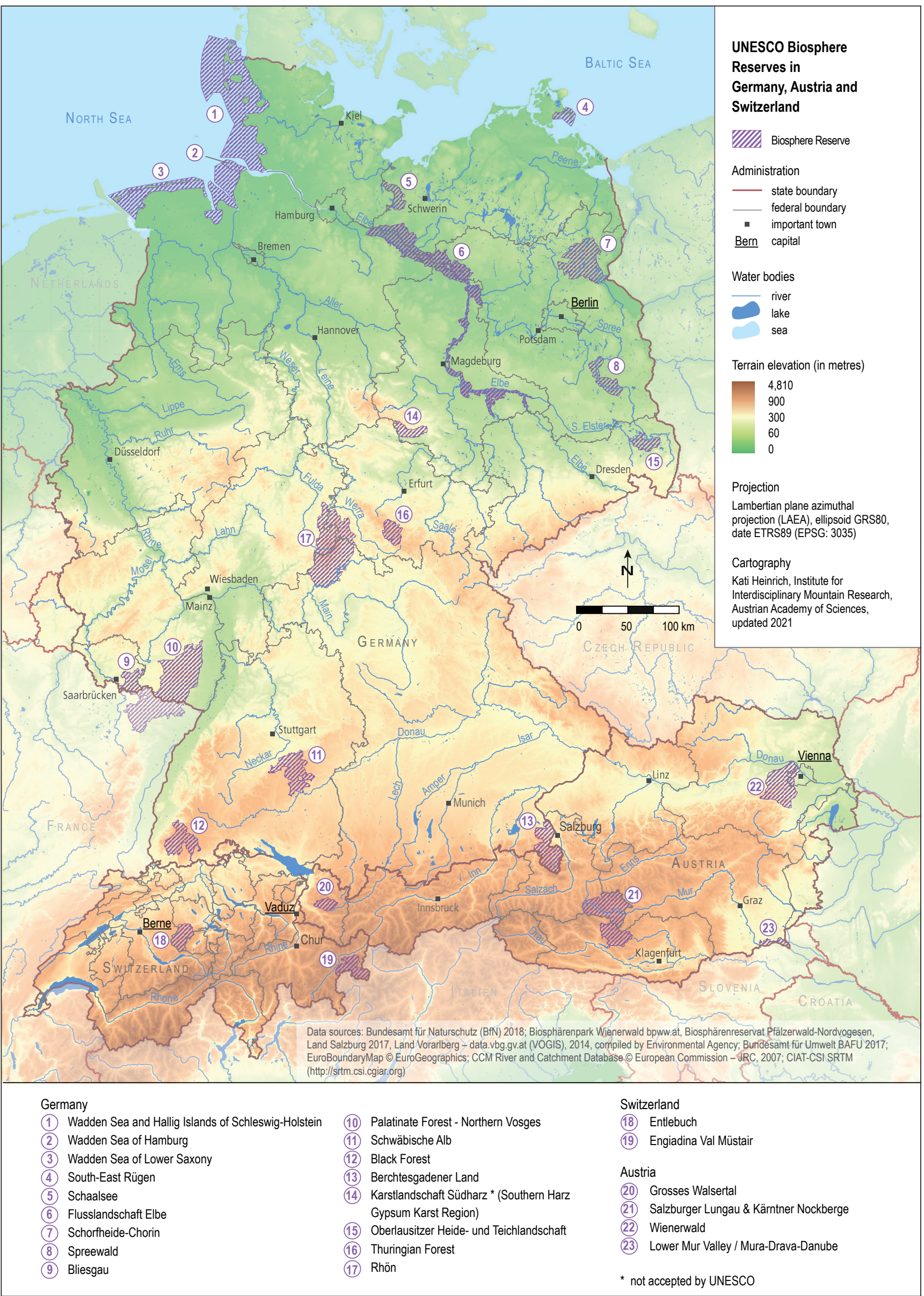

Figure 1 - Map of the BRs in the DACH region. 
The increasing use of raw materials and fossil fuels in the $20^{\text {th }}$ century led to the recreation of forest stands, but at the same time made the finiteness of certain resources visible. The roots of a globalized environmental movement can be identified in the scientific discourses of the 1960s (e.g. Rachel Carson's Silent spring; Carson 1962). The photo of planet Earth taken by Apollo 8 on 24 December 1968 (Figure 3) has become one of the most powerful iconic images of the $20^{\text {th }}$ century (Harari 2015). Visualizing and symbolizing the beauty and vulnerability of the planet, the photograph may have had a significant impact on scholarly discussions of the early 1970s. This decade was formative for diverse concepts of nature conservation: the MAB programme (1970/1971), the United Nations Environment Programme (1972), the Ramsar Convention as the first international nature conservation agreement (1971), the adoption of the World Heritage Convention (1972), and even the first European Year of Nature Conservation (1970) all took place practically simultaneously shortly after the picture was taken. In 1970, Bavaria was the first state to establish a State Ministry for Regional Development and Environmental Affairs. It was not only the first environmental ministry in Germany, but also the first anywhere in the world (Merkel 2010). When in 1972 the scientists around Denis Meadows published the results of their simulation project on the use of resources under the title Limits to growth (Meadows et al. 1972), they sharpened awareness of the finiteness of natural resources and of the urgent need for an international environmental policy.

The SDGs of the $21^{\text {st }}$ century, with their focus on justice or equity, introduce an ethically-based concept of sustainability that goes beyond scientific methods and discourses (Figure $2 \& 4$ ). While a concept of sustainability that focuses on needs, stocks, yields and limits raises technical, scientific and economic questions, justice raises complex moral, ethical and philosophical questions. The SDGs focus on equity (e. g., between countries of the Global North and the Global South, between generations, between different social groups, across social constructs of gender and race). In more than 60 of the 178 targets of the SDGs, equity is addressed explicitly; in many others, it is addressed indirectly. This is a significant expansion of the concept of sustainability towards global ethical and philosophical questions (Borsdorf \& Jungmeier 2020). Overall, in both scientific and political discourse, it can be seen that the notion and definition of sustainability have gradually expanded. In addition, the term has gained an imperative, ethical-appellative charge (Heintel \& Krainer 2014).

\section{State of research and recent discourses}

Initially, the MAB programme, which started as an international interdisciplinary research programme, and the resulting BRs were a science-driven programme (Nguyen et al. 2011). Many MAB National

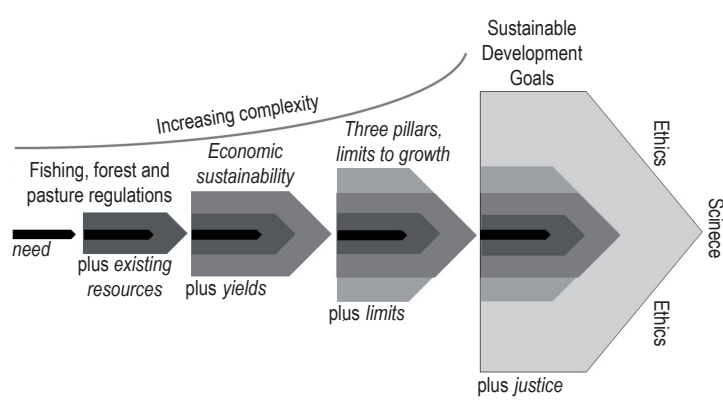

Figure 2 - SDGs as an ethical concept. Extension of the term sustainability in practical, scientific and ethical discourse (Borsdorf \& Jungmeier 2020, adapted).

Committees / Focal Points are still anchored in scientific disciplines, and are thus well rooted in academia. Furthermore, regular reflection, evaluation and adaptation, which were later conceptualized as adaptive management (Dudley et al. 2000), have a clear focus on scientific principles.

Accompanying research for the development of individual BRs as well as of the WNBR is a constituent element of the BR concept (see e. g. Moreira-Muñoz \& Borsdorf 2014). In recent years, numerous case studies have been published that refer to specific sites (e.g. Coy \& Weixlbaumer 2009; Farghaly et al. 2016; Kratzer 2018; Rumpolt et al. 2016; Schmitz et al. 2017; Speelman et al. 2014; Mayer et al. 2018; Carius \& Job 2019), or to supraregional or international developments (e.g. Hammer et al. 2016; Popelier \& Vaessen 2014; Roth 2017; Sacchetti \& Campbell 2017; Stoll-Kleemann \& Welp 2008). The approaches, methods and tools of governance and management are under permanent scientific review and modification. These include the development of robust and meaningful monitoring systems (e.g. Buer et al. 2013; Jungmeier et al. 2011, 2013; Runst \& Stoll-Kleemann 2020), and the acceptance by, and participation of, the population (e.g. German Commission for UNESCO 2015; Huber \& Arnberger 2016; Rumpolt 2009; von Lindern et al. 2020; Wallner \& Wiesmann 2009). Specific management issues include MIDAS (Multi Internationally Designated Sites; Schaaf \& Clamote Rodrigues 2016), transboundary management (Taggert-Hodge \& Schoon 2016), effective zoning systems (Wattendorf et al. 2017), and questions related to the Anthropocene (Egner \& Jungmeier 2018). BRs trigger scholarly debates on social innovation and entrepreneurship (e.g. Francis 2009; Bergstrand et al. 2011; Knaus et al. 2017; The Scottish Government 2015; Sacchetti \& Campbell 2017; Job et al. 2013; Kraus et al. 2014), and on conceptual and basic considerations, such as size of core areas or functions (Deutscher Rat für Landschaftspflege 2010; Egner \& Jungmeier 2018; Jiménez et al. 2017; Köck \& Arnberger 2017; Mose \& Weixlbaumer 2012; PichlerKoban \& Jungmeier 2015; Pichler-Koban \& Jungmeier 2017; Stoll-Kleemann \& O'Riordan 2018; Plieninger et al. 2016; Pütz \& Job 2016). New developments in re- 


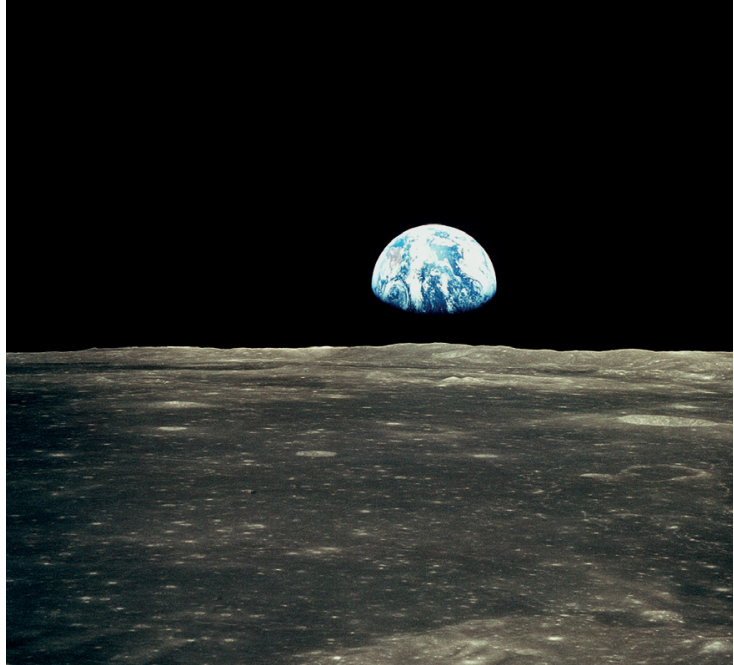

Figure 3 - Earthrise. Iconic picture of the $20^{\text {th }}$ century, mankind's first view of their own planet. Image courtesy of the Earth Science and Remote Sensing Unit, NASA Johnson Space Center. Photo ID AS11-44-6550, taken 1968 by Apollo 11. (C) Earth Science and Remote Sensing Unit, NASA Johnson Space Center, https:/ / eol.jsc.nasa.gov

search (e. g. Bela et al. 2016; Grasser et al. 2016; Petridis et al. 2017), education (Herrero 2017; Mammadova 2017), and integration and inclusion (e.g. Höglhammer et al. 2015) have also become visible.

\section{Research questions, approaches and methods}

In the context of 50 years of the MAB programme, we wish to focus on the development, current state and future perspective of BRs in the DACH countries. An assessment of the situation aims to contribute to international discussion. The research addresses the following questions related to BRs in the DACH countries:

- Past (P1): What are significant milestones in the historical development?

- Past (P2): What significant developments have been initiated by the BRs?

- The situation today (T1): What are the special features and characteristics of BRs?

- The situation today (T2): What are the particular strengths and weaknesses of BRs?

- Future (F1): What are the burning issues for the future of BRs?

- Future (F2): To which societal questions should BRs contribute in a distinctive way in order to shape the future?

The research project shall contribute equally to regional, national and international reflection. In particular, it will aim: (1) to initiate or support discussion among the BRs' management committees and stakeholders of the concepts of sustainability, justice or equity, and SDGs; (2) to support the BRs' management in implementing the SDGs through concrete recommendations and applied research questions; (3) to promote scientific discourses about issues relevant for the further development of the BR concept and of BRs in practice.

The research was conducted over a period of three years (2018-2020). In the first step, the current or very recent situation, discussions and developments of BRs in DACH were assessed. In preparation for a book (Biosphere 4.0, Borsdorf et al. 2020), an open call was launched for contributions from academics, BR managers, planners and consultants that looked at and analysed the current status of BRs. The call resulted in 18 scientific articles, all of which underwent a doubleblind peer review. Hence, these articles constitute an important information basis, highlighting different aspects, questions and research results.

In the second phase, the articles were subjected to a meta-analysis. First, we screened all articles and developed the research questions given above, deriving them from the existing literature and the 18 new articles. These questions were used for a qualitative survey that was implemented online using Survey monkey. Thirty-three quite diverse contributing authors were involved in the inquiry as well as in the interpretation of the results (Table 1). The results were condensed to hypotheses, which were refined in a joint virtual workshop (8 September 2020). The discussion was conducted in the program Miro, using a virtual whiteboard in connection with Zoom technology, and led to the revised and finalized results as presented in this article.

\section{Results: BRs in the $\mathrm{DACH}$ region}

Overview of recent research findings in the $\mathrm{DACH}$ region

In a comprehensive scientific analysis, Borsdorf et al. (2020) investigate the current state of BRs in the region; together with authors from the three DACH countries, they draw a picture of a Biosphere $4.0-\mathrm{a}$ potentially new generation of BRs (for more information, see Supplementary Table 1).

Past (P1): What are significant milestones in the historical development of BRs in the DACH region?

Based on Bridgewater (2016), Hadley (2006) and Job et al. (2019), Braun et al. (2020) identified phases in the development of the BR concept and in establishing BRs. The historical development of BR territories in Austria, Germany and Switzerland illustrates and underlines how international policies and repeated paradigm-shifts had a visible impact on the ground (see Köck \& Arnberger 2017; Weixlbaumer et al. 2020). The fact that changed and new policies are having an effect suggests that the BRs in the $\mathrm{DACH}$ region are not simply sites of learning for sustainable practices, but are indeed themselves also learning systems that respond flexibly to new developments and findings. 

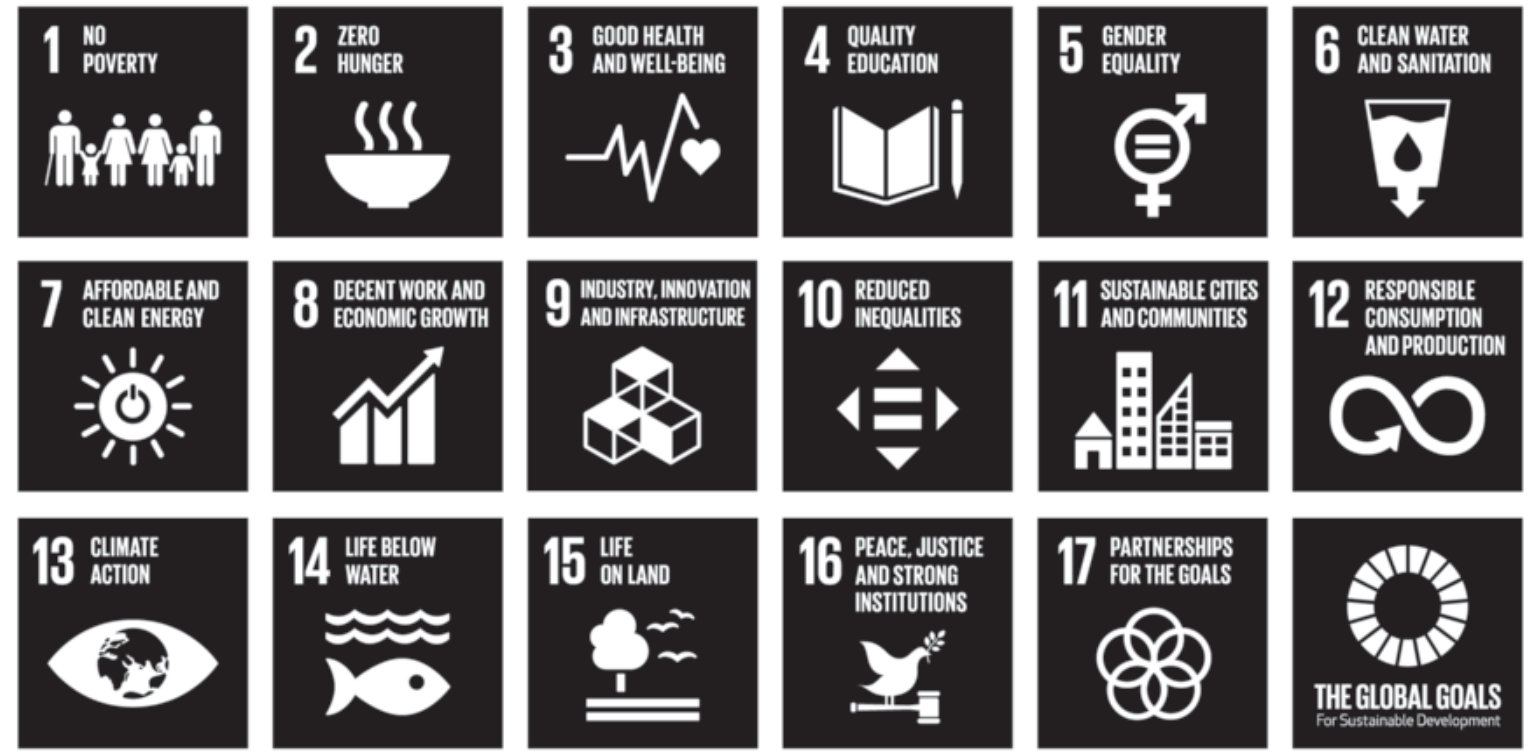

Figure 4 - Sustainable Development Goals. A global orientation towards sustainability (United Nations 2015).

However, it can take many years before just some of the conceptual and strategic considerations find their realization in regional management plans. One reason is that participative processes to define targets require time, and management plans usually cover a period of 10 years. Although minor adjustments to new policies can be implemented continuously, major amendments may be realized only in later management plans.

Past (P2): What significant developments have been initiated by the BRs in the $\mathrm{DACH}$ region?

The Seville Strategy introduced the three connected functions of BRs: conservation, development and logistical support. These functions are intended to facilitate the protection of valuable natural and cultural landscapes while also meeting the requirements of the people living in those landscapes (Köck \& Arnberger 2017; Braun et al. 2020). The conservation function contributes to maintaining and enhancing biodiversity within the three zones of the BRs. DACH BRs generally aim to implement integrative concepts that take into consideration classic nature conservation as well as economic, social and other ecological interests. However, the conservation function takes a back seat to economic development. More emphasis should be placed on living in harmony with nature, i.e. preserving diversity as the basis for sustainable development. The development function contributes to the creation of greater added value for the region (e.g. through value chains, cooperation, regional products and services), while at the same time maintaining and enhancing biological diversity, landscape qualities, and social and cultural aspects, thus ensuring sustainable regional development. Within the support function, the importance of democratic processes, participation and acceptance at regional level should be strengthened; the importance given to science and research should be enhanced; access by (peripheral) regions to scien- tific knowledge and institutions should be improved, and education for sustainable development should be promoted. A selection of the numerous ways in which the three functions are implemented in the BRs of the DACH region are presented in Supplementary Table 1 . The variety of the examples corresponds to the diversity of the BRs and represents the respective regions well, but each BR must also set its own priorities taking into account the limits on its own resources (money, personnel, etc.). However, the DACH BRs should contribute their expertise more strongly to the WNBR. In order to do justice to new developments, further focal points should also be set, such as population decline, demographic change, migration, mobility and sub-urbanization.

The situation today (T1): What are the special features and characteristics of BRs in the DACH region?

Germany, Austria and Switzerland are federal states in which land ownership, political stability and decentralized decision-making are of great importance. Democracy and the rule of law play an essential role. The BRs in these countries are characterized by comprehensive, very diverse and regionally different participatory possibilities. This is visible in the diversity of organizational forms and legal implementation. Supporting structures are, for example, public administration entities (municipal, regional), associations, companies (mostly non-profit), foundations, or other specific legal entities. This diversity translates into a wide range of roles as regards (semi-)governmental authority, and also very diverse numbers of staff.

Nevertheless, the binding quality criteria of the Austrian and German MAB national committees and of the Swiss Federal Office for the Environment allow for implementation in accordance with international standards. The national quality stan- 
dards were developed in comprehensive processes (Lange 2005; Deutsches MAB-Nationalkomitee 2007; Österreichisches MAB-Nationalkomitee 2016, 2017, 2018) and are an essential element of quality assurance in federal states that have many decentralized tasks and actors. Most of the BRs in the DACH region comply with the zoning requirements laid out in the Seville strategy. The three BRs on the Wadden Sea, however, all created since Seville, have yet to finalize their zoning and are currently trying to expand beyond the existing national park boundaries. They will then be evaluated for recognition by UNESCO in 2022 with the new perimeters; their merger into a single Wadden Sea BR is also on the cards in the longer term. In this context, it is worth mentioning that Austria has removed four BRs from the list because they did not meet the Seville criteria. National and international networking are taken seriously. Striking a balance between protection and use is always aimed for. The high standards with regard to innovation raise a number of fundamental questions, such as how innovative a BR must be, how to measure innovative strength, and how a BR as an intermediary institution can drive both structural and entrepreneurial innovation.

The situation today (T2): What are the particular strengths and weaknesses of $\mathrm{BRs}$ in the $\mathrm{DACH}$ region?

Among the particular strengths of BRs in the $\mathrm{DACH}$ region are the well-established participative processes (e.g. stakeholder involvement regarding BR designation and evaluation, and in drawing up management plans), democratic legitimacy, political support, the legal status of BR conferred by nature conservation laws, and cooperation between institutions (regional, national and international networking). Most BRs are regionally well anchored, local people express high acceptance of the BR in their area (von Lindern et al. 2020), and most BRs offer a wide range of sustainable development instruments and projects, particularly for peripheral regions. Thanks to the BR managements, projects and initiatives are mostly well conceived, initiated, implemented and supported. The BRs use their potential to develop into regions for real innovation and experiment. Those in DACH comprise very different types of landscape; most of them are extensive, traditionally used, cultural landscapes (Braun et al. 2020) and have high-quality standards oriented towards international developments and steered by the MAB national committees based on MAB's quality criteria. The BRs have a high degree of credibility because in the DACH countries some BRs have already been withdrawn voluntarily from the WNBR for no longer complying with current aims and criteria.

Furthermore, there are many examples of excellent visitor and environmental education offers. Awareness of sustainability topics is increasing and is generally well established among stakeholders and inhabitants of the BRs (von Lindern et al. 2020). The BRs have developed good skills in initiating projects and in helping to support them both financially and in terms of human resources, even managing and implementing some projects themselves. In general, they also offer good opportunities for research and actively seek cooperation with scientific institutions. Marketing of BRs and the communication of sustainability topics are well established in most BRs. All BRs put a great deal of effort into monitoring their own activities. In Austria, the MAB National Committee offers funding for research projects, which are carefully approved in advance through an international peer-review process. A similar process is in place in Germany. The MAB National Committee in Austria has published several books. These include publications on local cuisine in BRs (Köck \& Umhack 2011); on international examples (both good and less commendable ones) of mountain BRs (Austrian MAB Committee 2011); and a monograph on Chilean BRs (Moreira-Muñoz \& Borsdorf 2014). The history of the journal eco.mont goes back to a joint initiative between the International Scientific Committee on Research in the Alps (ISCAR) and the network of alpine protected areas ALPARC, both of which are connected to the MAB programme.

The weaknesses of the BRs are partly due to the broad integration of the various interests and institutions at different regional levels (federal government, regional and local administrations), because of the federal structures of the DACH countries. The coordination of the different levels is time-consuming, and decision-making processes sometimes take a considerable time. For regional development initiatives to be truly sustainable, BRs need the active involvement of local stakeholders, businesses and the general population. Where this is lacking, there are significant deficits in implementation. It is typical of intensive participative processes that they require time and resources for all stakeholders' opinions to be discussed. Poorly prepared participation processes would cause considerable difficulties. This is why setting up new BRs involves enormous effort and resources. In view of the diversity of their tasks, BRs often see themselves as being under-resourced and lacking in political support compared to other protected area categories, such as national parks. Some workshop participants in our study argued that the transformative potential of BRs is not being used to the full at the political level.

Numerous specific weaknesses and opportunities for improvement can be identified in individual BRs and countries, or in relation to specific questions (e.g., insufficient financing instruments due to a lack of treaties between federal state and provinces in Austria; some German BRs see the term Reservat as a barrier, etc.). Overall, BRs in the DACH countries are well on their way to fulfilling the aims of BRs, but this must be continued and intensified in order to respond to the urgent ecological challenges as well as economic and social interests. Special attention should continue to be paid to the development of urban and cross-border 
BRs. A successful example of the latter is the FrancoGerman BR Pfälzerwald-Nordvogesen.

Future (F1): What are the burning issues for the future of $\mathrm{BRs}$ in the $\mathrm{DACH}$ region?

The original intention to integrate man and biosphere within the management of BRs and to find a continuous balance between protection and uses has not changed. Both the number of questions raised and their complexity have increased significantly. In addition, very different questions have arisen in individual areas as a result of BRs' diverse ecological, economic and social conditions. The burning issues need to be dealt with individually, but a meta-methodology is needed to make the results generalizable and transferable. If a BR does not succeed in setting appropriate priorities and structuring goals and activities, or in attracting additional funding, there is always the risk of overburdening and overstretching the BR concept locally.

Future (F2): To which societal questions should BRs in the $\mathrm{DACH}$ region contribute in a special way for the future?

The BRs claim to take up social discourses in a comprehensive way and to contribute to solutions. They integrate major social issues such as migration, integration, inclusion, global change (in particular climate change), digitization, justice or equity, and mobility, as well as adequate performance, the post-growth economy, innovation and ecosystem services, and place them in their respective regional contexts. However, sustainability remains the central generic term. But these issues can only be addressed in reliable partnerships and in cooperation with the local populations and their interests. To avoid arbitrariness of the topics or overburdening BRs' managements and stakeholders, the BRs should develop individual future agendas that are complementary to each other at national and international levels, without losing sight of the three core BR functions. Scientific research will remain a key success factor to support transformation processes of BRs in the future (Scheurer 2020).

\section{Discussion and conclusion}

With their commitment to further developing BRs into model regions for implementing sustainability goals, BR managements face new challenges. BRs are well placed to continue spreading the idea of sustainable development in all regional fields of activity - and this they must do if they are to continue to fulfil their mission of being spaces of innovation for nature conservation, since they are explicitly supposed to integrate protection and use. This also means taking up the more recent discussions on, for example, environmentally friendly forms of mobility and lifestyle and, together with other actors, assuming a pioneering role in their regions.
There is a danger that BRs addressing sustainable development in the sense of all SDGs will overstretch themselves and dissipate their portfolios, leading to them becoming management bodies for all concerns related to sustainable development. This would be an impossible task and must not be allowed to happen. Nevertheless, BRs must give more thought to how they can take up the SDGs and what priorities they want to set against the background of the SDGs. Additionally, the framework of the Madrid Action Plan for BRs states that "The role of biosphere reserves is essential to rapidly seek and test solutions to the challenges of climate change as well as monitor the changes as part of a global network. [...] [B] iosphere reserves can be areas for demonstrating adaptation measures for natural and human systems, assisting the development of resilience strategies and practices." In summary, the basic mission of a BR is nature conservation and biodiversity preservation, and how to anchor these in the region through regional climate protection measures, while addressing questions of mobility, lifestyle and livelihood, so that social and economic added value is also created.

BRs in Germany, Austria and Switzerland have sufficient experience in integrating nature conservation and preservation of biodiversity into regional resource-use and regional development. Thanks to their participatory procedures, mostly long-term cooperation with local actors, and relatively high acceptance among the population, they are well equipped to take up other topics in the 2030 Agenda with actors and to initiate appropriate projects, if political support can be increased. Within the network of BRs in the $\mathrm{DACH}$ region, only Germany has as many as $90 \%$ of its landscape biomes covered by BRs (Job et al. 2019). The representation of a sub-urban BR has so far been achieved only by Austria, with the BR Wienerwald. The aims throughout the DACH region should be to represent all landscape and cultural areas, and therefore to create further BRs.

\section{References}

Ammering, U., M. Coy, L. Kindl, A. Kratzer, T. Töpfer \& N.A. de Mello-Téry 2020. Am Rand großer Städte - Urbane Biosphere Reserves zwischen Konzept und Umsetzung. In: Borsdorf, A., M. Jungmeier, V. Braun \& K. Heinrich (eds.), Biosphäre 4.0 UNESCO Biosphere Reserves als Modellregionen einer nachbaltigen Entwicklung: 185-202.

Austrian MAB Committee (ed.) 2011. Biosphere Reserves in the Mountains of the World. Excellence in the Clouds? Wien.

Bela, G., T. Peltola, J.C. Young, B. Balázs, I. Arpin, G. Pataki, J. Hauck, E. Kelemen, L. Kopperoinen, A. Herzele \& H. Keune 2016. Learning and the Transformative Potential of Citizen Science. Conservation Biology 30(5): 990-999. Doi: 10.1111/cobi.12762

Bergstrand, B.-O., F. Björk \& S. Molnar 2011. Biosphere Entrepreneurship - A pilot study on social entrepreneur- 
ship in the biosphere reserve Lake Vänern Archipelago and Mount Kinnekulle, Sweden. Available at: http://media. vanerkulle.org/2013/09/297_Biosphere-Entrepreneurship-A-Pilot-Study-Webversion.pdf (accessed: 05/10/2020)

Borsdorf, A. \& M. Jungmeier 2020. Das Weltnetz der Biosphere Reserves (UNESCO WNBR) im Spiegel des Nachhaltigkeitskonzeptes: Stand und Perspektiven. In: Borsdorf, A., M. Jungmeier, V. Braun \& K. Heinrich (eds.), Biosphäre 4.0 - UNESCO Biosphere Reserves als Modellregionen einer nachhaltigen Entwicklung: 3-32.

Borsdorf, A., M. Jungmeier, V. Braun \& K. Heinrich (eds.) 2020: Biosphäre 4.0 - UNESCO Biosphere Reserves als Modellregionen einer nachbaltigen Entwicklung.

Borsdorf, F. 2020. Bürgerbeteiligung und Sozialkapital in Schutzgebieten: Resultate einer Studie im Biosphärenpark Großes Walsertal. In: Borsdorf, A., M. Jungmeier, V. Braun \& K. Heinrich (eds.), Biosphäre 4.0 - UNESCO Biosphere Reserves als Modellregionen einer nachbaltigen Entwicklung: 203-212.

Braun, V., A. Humer-Gruber, K. Heinrich \& H. Job 2020. Synopsis der Biosphere Reserves in Deutschland, Österreich und der Schweiz. In: Borsdorf, A., M. Jungmeier, V. Braun \& K. Heinrich (eds.), Biosphäre 4.0 - UNESCO Biosphere Reserves als Modellregionen einer nachbaltigen Entwicklung: 33-60.

Bridgewater, P. 2016. The Man and Biosphere programme of UNESCO: rambunctious child of the sixties, but was the promise fulfilled? Current Opinion in Environmental Sustainability 19: 1-6.

Buer, C., F. Solbrig \& S. Stoll-Kleemann (eds.) 2013. Sozioökonomisches Monitoring in deutschen UNESCOBiosphärenreservaten und anderen Großschutzgebieten. BfNSkripten 329. Bonn.

Carius, F. \& H. Job 2019. Community involvement and tourism revenue sharing as contributing factors to the UN Sustainable Development Goals in Jozani-Chwaka Bay National Park and Biosphere Reserve, Zanzibar. Journal of Sustainable Tourism 27(6): 826-846.

Carlowitz, H.C. 1713. Sylvicultura Oeconomica haußwirthliche Nachricht und Naturmäßige Anweisung zur wilden Baum-Zucht. Leipzig.

Carson, R. 1962. Silent spring. Boston.

Coy, M. \& N. Weixlbaumer (eds.) 2009. Der Biosphärenpark als regionales Leitinstrument. Das Große Walsertal im Spiegel der Nutzer. alpine space - man \& environment 10. Innsbruck. Available at: https://www. uibk.ac.at/iup/buch_pdfs/alpine_space_vol.10.pdf (accessed: 18/10/2020)

Deutscher Rat für Landschaftspflege 2010. Biosphärenreservate sind mehr als Schutagebiete - Wege in eine nachbaltige Zukunft. Schriftenreihe des Deutschen Rates für Landschaftspflege 83. Meckenheim. Available at: http://www.landespflege.de/schriften/DRL_SR83. pdf (accessed: 05/10/2020)

Deutsches MAB-Nationalkomitee 2007. Kriterien für die Anerkennung und Überprüfung von Biosphärenreservaten der UNESCO in Deutschland. Bonn. Available at:
https://www.bfn.de/fileadmin/BfN/gebietsschutz/ Dokumente/BR_Kriterien_nat_deutsch_07.pdf (accessed: 05/10/2020)

Deutsches MAB-Nationalkomitee 2017. Positionspapier des deutschen MAB-Nationalkomitees zur Zonierung in UNESCO-Biosphärenreservaten in Deutschland (Entwurf). Bonn. Available at: https://www.bfn.de/fileadmin/ $\mathrm{BfN} /$ internationalernaturschutz/Dokumente/MAB/ Positionspapier_Kernzonen_2017_bf.pdf (accessed: 05/10/2020)

Dudley, N., M. Hockings \& S. Stolton 2000. Evaluating Effectiveness. A Framework for Assessing the Management of Protected Areas. Best Practice Protected Area Guidelines Series 6: Cambridge, IUCN.

Egner, H., J. Falkner, M. Jungmeier \& D. Zollner 2017. Institutionalizing cooperation between biosphere reserves and universities - the example of Science_Linknockberge. eco.mont - Journal on Protected Mountain Areas Research and Management 9(2): 77-80. Doi: 10.1553/eco.mont-9-2s77

Egner, H. \& M. Jungmeier 2018. Non-territorial nature conservation? On protected areas in the Anthropocene. Annals of the Austrian Geographical Society 160: 115-142. Doi: 10.1553/moegg160s115

Falkner, J. \& F. Rauch 2020. SCiENCE_LINK ${ }^{\text {nock- }}$ berge - kooperativ Forschen, Lehren und Lernen. In: Borsdorf, A., M. Jungmeier, V. Braun \& K. Heinrich (eds.), Biosphäre 4.0 - UNESCO Biosphere Reserves als Modellregionen einer nachhaltigen Entwicklung: 161-170.

Farghaly, D., E. Elba \& B. Urban 2016. Towards Sustainable Land Uses within the Elbe River Biosphere Reserve in Lower Saxony, Germany by Means of TerraSAR-X Images. Journal of Geoscience and Environment Protection 4: 97-121.

Filli, F. \& A. Abderhalden 2020. Der Weg vom Réserve de Biosphère Parc Suisse zum UNESCO Biosphärenreservat Engiadina Val Müstair: eine basisdemokratische Herausforderung. In: Borsdorf, A., M. Jungmeier, V. Braun \& K. Heinrich (eds.), Biosphäre 4.0 - UNESCO Biosphere Reserves als Modellregionen einer nachbaltigen Entwicklung: 255-264.

Francis, G. 2009. Canadian Biosphere Reserves and social innovations: an exploration. Unpublished draft.

German Commission for UNESCO (eds.) 2015. Management Manual for UNESCO Biosphere Reserves in Africa. Available at: https://www.unesco.de/sites/ default/files/2018-01/Manual_BR_Africa_en-1.pdf (accessed: 14/10/2020)

Grasser, S., C. Schunko \& C.R. Vogl 2016. Children as ethnobotanists: methods and local impact of a participatory research project with children on wild plant gathering in the Grosses Walsertal Biosphere Reserve, Austria. Journal of Ethnobiology and Ethnomedicine 12(46): $1-16$.

Grober, U. 2010. Die Entwicklung der Nachbaltigkeit. Kulturgeschichte eines Begriffes. München.

Hadley, M. 2006. A practical ecology. The Man and the Biosphere (MAB) Programme. Sixty years of science at UNESCO 1945-2005: 260-296. 
Hammer, T., F. Knaus \& A. Schmid 2020. Welchen Beitrag kann ein Biosphere Reserve zur Umsetzung der SDG leisten? Einsichten und Aussichten aus der UNESCO Biosphäre Entlebuch. In: Borsdorf, A., M. Jungmeier, V. Braun \& K. Heinrich (eds.), Biosphäre 4.0 - UNESCO Biosphere Reserves als Modellregionen einer nachbaltigen Entwicklung: 303-324

Hammer, T., I. Mose, D. Siegrist \& N. Weixlbaumer (eds.) 2016. Parks of the future. Protected areas in Europe challenging regional and global change. München.

Harari, Y.N. 2015. Eine kurze Geschichte der Menschbeit. München.

Heintel, P. \& L. Krainer 2014. Geschichtlich-kulturelle Nachhaltigkeit. Erwägen. Wissen. Ethik 25(4): 435-446.

Herrero, C. 2017. Biosphere Reserves: Learning spaces for sustainability. International Journal of UNESCO Biosphere Reserves 1(2): 77-84.

Höglhammer, A., A. Muhar \& T. Schauppenlehner 2015. Outdoor Recreation of Turkish Immigrants in the Wienerwald Biosphere Park, Austria - A Stakeholder Process to Identify Research Questions. In: Borsdorf, A., M. Jungmeier, V. Braun \& K. Heinrich (eds.), Biosphäre 4.0 - UNESCO Biosphere Reserves als Modellregionen einer nachhaltigen Entwicklung: 129-140.

Huber, M. \& A. Arnberger 2016. Opponents, wavers or supporters: the influence of place-attachment dimensions on local residents' acceptance of a planned biosphere reserve in Austria. Journal of Environmental Planning and Management 59(9): 1610-1628.

Huber, M. \& T. Köstl 2020. Nachhaltigkeit messen - Praktische Erfahrungen und Herausforderungen im Aufbau eines Biosphere Reserve Integrated Monitoring (BRIM) im Biosphärenpark Salzburger Lungau \& Kärntner Nockberge. In: Borsdorf, A., M. Jungmeier, V. Braun \& K. Heinrich (eds.), Biosphäre 4.0 - UNESCO Biosphere Reserves als Modellregionen einer nachbaltigen Entwicklung: 281-302.

Jiménez, Y., A. Caballero \& L. Porcel 2017. Conservation-Development duality: The Biosphere Reserve Sierra de Grazalema after 40 Years in the MaB programme. European Journal of Geography 8(2): 35-54.

Job, H., M. Engelbauer \& B. Engels 2019. Das Portfolio deutscher Biosphärenreservate im Lichte der „Sustainable Development Goals“. Raumforschung und Raumordnung 77(1): 57-79. Doi: org/10.2478/rara2019-0005

Job, H., F. Kraus, C. Merlin \& M. Woltering 2013. Wirtschaftliche Effekte des Tourismus in Biosphärenreservaten Deutschlands. Naturschutz und Biologische Vielfalt 134. Bonn-Bad Godesberg.

Jungmeier, M., M. Huber, D. Zollner \& H. Egner 2018. Zur Vermessung von Wissenslandschaften: Regionen als Träger, Produzenten und Nutzer von Nachhaltigkeitswissen - das Beispiel Biosphärenpark Salzburger Lungau und Kärntner Nockberge. Innovation and the public Sector 44(1): 7-22.

Jungmeier, M., T. Köstl, S. Lange \& M. Bliem 2013. The art of omission: BRIM ${ }^{\text {nockberge }}-$ designing a Biosphere Reserve Integrated Monitoring for the Carinthian part of the Biosphere Reserve Salzburger Lungau \& Kärntner Nockberge. eco.mont - Journal on Protected Mountain Areas Research and Management 5(2): 15-22. Doi: 10.1553/ecomont-5-2s15

Jungmeier, M., I. Paul-Horn, D. Zollner, F. Borsdorf, K. Grasenick, S. Lange \& B. Reutz-Hornsteiner 2011. Biosphere reserves as a long-term intervention in a region - strategy, processes, topics and principles of different participative planning and management regimes of biosphere reserves. eco.mont - Journal on Protected Mountain Areas Research and Management 3(1): 29-36. Doi: 10.1553/eco.mont-3-1s29

Knaus, F., L. Ketterer Bonnelame \& D. Siegrist 2017. The Economic Impact of Labeled Regional Products: The Experience of the UNESCO Biosphere Reserve Entlebuch. Mountain Research and Development 37(1): 121-130. Doi: 10.1659/ MRD-JOURNAL-D-16-00067.1

Köck, G. \& A. Arnberger 2017. The Austrian Biosphere Reserves in the light of changing MAB strategies. eco.mont - Journal on Protected Mountain Areas Research and Management 9(special issue): 85-92. Doi: 10.1553/ eco.mont-9-sis85

Köck, G., A. Arnberger \& L. Möller 2020. Agenda 2030 und Lima-Aktionsplan - Anpassung der Biosphere Reserves für die Zukunft. In: Borsdorf, A., M. Jungmeier, V. Braun \& K. Heinrich (eds.), Biosphäre 4.0 - UNESCO Biosphere Reserves als Modellregionen einer nachhaltigen Entwicklung: 61-84.

Köck, G. \& M. Umhack 2011. Vielfalt genießen. Wien.

Konold, W. 2020. Aus der Region heraus entstanden - das Biosphärengebiet Schwarzwald. In: Borsdorf, A., M. Jungmeier, V. Braun \& K. Heinrich (eds.), Biosphäre 4.0 - UNESCO Biosphere Reserves als Modellregionen einer nachhaltigen Entwicklung: 265-280.

Kratzer, A. 2018. Biosphere reserves as model regions for sustainability transitions? Insights into the peripheral mountain area Grosses Walsertal (Austria). Applied Geography 90: 321-330. Doi: 10.1016/j. apgeog.2017.04.003

Kratzer, A. 2020. Netzwerk Biosphere Reserves Einblicke in die Innovationspotentiale der Peripherie am Beispiel Entlebuch (Schweiz) und Großes Walsertal (Österreich). In: Borsdorf, A., M. Jungmeier, V. Braun \& K. Heinrich (eds.), Biosphäre 4.0 - UNESCO Biosphere Reserves als Modellregionen einer nachbaltigen Entwicklung: 139-160.

Kraus, F., C. Merlin \& H. Job 2014. Biosphere Reserves and their Contribution to Sustainable Development: A Value-Chain Analysis in the Rhön Biosphere Reserve, Germany. Zeitschrift für Wirtschaftsgeographie 58(2-3): 164-180.

Lange, S. 2005. Inspired by Diversity. The Austrian Contribution to UNESCO's MAB programme. Created at the Institute for Urban and Regional Research. Wien.

Mammadova, A. 2017. Biosphere Reserve as Learning Sites for Biocultural Conservation Education; Case of Mount Hakusan Biosphere Reserve in Japan. Eu- 
ropean Journal of Sustainable Development 6(4): 487-496. Doi: 10.14207/ejsd.2017.v6n4p487

Mayer, M., L. Brenner, B. Schauss, C. Stadler, J. Arnegger \& H. Job 2018. The Nexus Between Governance and the Economic Impact of Whale-Watching. The Case of the Coastal Lagoons in the El Vizcaíno Biosphere Reserve, Baja California, Mexico. Ocean and Coastal Management 162: 4-59.

Meadows, D.H., D.L. Meadows, J. Randers \& W.W. Behrens 1972. The Limits to Growth.

Merkel, A. 2010. Grußwort anlässlich der Festveranstaltung „40 Jahre Bayerische Umweltpolitik“" am 26. November 2010 in München. Available at: https://www. stmuv.bayern.de/ministerium/aufgaben/doc/grusswort_bundeskanzlerin_angela_merkel.pdf (accessed: 14/12/2020)

Moreira-Muñoz, A. \& A. Borsdorf (eds.) 2014. Reservas de la Biosfera de Chile. Laboratorios para la Sustentabilidad. GEOlibros 17. Santiago de Chile: Pontificia Universidad Católica de Chile.

Mose, I. \& N. Weixlbaumer 2012. A Shift of Paradigm? Protected Areas Policies in Europe in Transition - by the Example of the Hohe Tauern National Park. In: Weixlbaumer, N. (ed.), Anthologie zur Sozialgeographie. Abhandlungen zur Geographie und Regionalforschung 16: 106-124. Wien.

Nguyen, N.C., O.J.H. Bosch \& K.E. Maani 2011. Creating „Learning laboratories for sustainable development" for UNESCO Biosphere Reserves. A Systems Thinking Approach. Systems Research and Behavioral Science 28: 51-62. Doi: 10.1002/sres.1044

Österreichisches MAB-Nationalkomitee 2016. Kriterien für Biosphärenparks in Österreich. Wien. Available at: http://www.biosphaerenparks.at/images/ pdf/CriteriaAustrianBR_2016_eng.pdf (accessed: 09/10/2020)

Österreichisches MAB-Nationalkomitee 2017. Positionspapier des Österreichischen Nationalkomitees für das UNESCO-Programm „Man and the Biosphere (MAB) "zur Nutzung von erneuerbaren Energien in österreichischen Biosphärenparks. Wien.

Österreichisches MAB-Nationalkomitee 2018. Austrian Contributions to UNESCO's Man and the Biosphere Programme (MAB). Summary Report for the Year 2017. Vienna.

Österreichisches MAB-Nationalkomitee 2021. UNESCO genehmigt weltweit ersten Fünf-LänderBiosphärenpark "Mur-Drau-Donau" (TBR MDD). Wien. Available at: http://www.biosphaerenparks. at/index.php/de/blog/107-unesco-genehmigtweltweit-ersten-f\%C $3 \% \mathrm{BCnf}-1 \% \mathrm{C} 3 \% \mathrm{~A} 4 \mathrm{nder}-$ biosph $\% \mathrm{C} 3 \% \mathrm{~A} 4$ renpark-mur-drau-donau-tbr-mdd (accessed: 30/09/2021)

Petridis, P., M. Fischer-Kowalski, S.J. Singh \& D. Noll 2017. The role of science in sustainability transitions: citizen science, transformative research, and experiences from Samothraki island, Greece. Island Studies Journal 12(1): 115-134. Doi: 10.24043/isj.8
Pichler-Koban, C. \& M. Jungmeier 2015. Naturschutz, Werte, Wandel. Die Geschichte ausgewählter Schutzgebiete in Deutschland, Österreich und der Schweiz. Bern.

Pichler-Koban, C. \& M. Jungmeier 2017. Alpine parks between yesterday and tomorrow - a conceptual history of Alpine national parks via tourism in charismatic parks in Austria, Germany and Switzerland. eco. mont - Journal on Protected Mountain Areas Research and Management 9 (special issue): 17-28. Doi: 10.1553/eco. mont-9-sis17

Plieninger, T., M. Woltering \& H. Job 2016. Implementierung des Ökosystemleistungs-Ansatzes in deutschen Biosphärenreservaten. Raumforschung und Raumordnung 74(6): 541-554.

Popelier, L. \& J. Vaessen 2014. Final Evaluation of the Madrid Action Plan for Biosphere Reserves. UNESCO (IOS/EVS). Paris.

Pütz, M. \& H. Job 2016. Governance und Regionalentwicklung in Großschutzgebieten der Schweiz und Österreichs. Raumforschung und Raumordnung 74(6): 569-583.

Roth, A. 2017: \#ProudToShare - Good Practices in French Biosphere Reserves. MAB France and AFB. Toulouse.

Rumpolt, P.A. 2009. Das Selbstbild im Biosphärenpark Großes Walsertal. In: Coy, M. \& N. Weixlbaumer (eds.), Der Biosphärenpark als regionales Leitinstrument. Das Große Walsertal im Spiegel der Nutzer. alpine space man \& environment 10: 43-62. Innsbruck. Available at: https://www.uibk.ac.at/iup/buch_pdfs/alpine_ space_vol.10.pdf (accessed: 18/10/2020)

Rumpolt, P.A. 2020: Der Biosphärenpark Großes Walsertal aus dem Blickwinkel seiner Bewohnerinnen und Bewohner. In: Borsdorf, A., M. Jungmeier, V. Braun \& K. Heinrich (eds.), Biosphäre 4.0 - UNESCO Biosphere Reserves als Modellregionen einer nachbaltigen Entwicklung: 213-226.

Rumpolt, P.A., A. Kratzer, M. Coy \& N. Weixlbaumer (eds.) 2016. REPA next. Regional Economic and Perceptional Analyses in an UNESCO Biosphere Reserve. Future strategies for regional development in the BR Großes Walsertal against the background of demographic change: What comes next? Wien, Innsbruck. Doi: 10.1553/ MAB-REPA-Next

Runst, U.J. \& S. Stoll-Kleemann 2020. Akzeptanzfördernde Faktoren im Biosphärengebiet Schwäbische Alb - Ein Fallbeispiel für eine gelingende Integration von Mensch und Biosphäre. In: Borsdorf, A., M. Jungmeier, V. Braun \& K. Heinrich (eds.), Biosphäre 4.0 - UNESCO Biosphere Reserves als Modellregionen einer nachbaltigen Entwicklung: 171-185.

Sacchetti, S. \& C. Campbell 2017. Biosphere Reserves: An "Enabling Space" for Communities. Journal of Entrepreneurial and Organisational Diversity 6(1): 1032. Doi: $10.5947 /$ jeod.2017.002

Schaaf, T. \& D. Clamote Rodrigues 2016: Managing MIDAs: Harmonising the management of Multi- Internationally Designated Areas: Ramsar Sites, World Heritage sites, Biosphere Reserves and UNESCO 
Global Geoparks. Gland, Switzerland. Doi: 10.2305/ IUCN.CH.2016.03.en

Scheurer, T. 2020. Das MAB-6-Projekt der UNESCO: Von der Ökosystemforschung zum MAB Biosphere Reserve. In: Borsdorf, A., M. Jungmeier, V. Braun \& K. Heinrich (eds.), Biosphäre 4.0 - UNESCO Biosphere Reserves als Modellregionen einer nachbaltigen Entwicklung: 85-98.

Schmitz, M.F., C. Arnaiz-Schmitz, C. HerreroJáuregui, P. Díaz, D.G.G. Matos \& F.D. Pineda 2017. People and nature in the Fuerteventura Biosphere Reserve (Canary Islands): socio-ecological relationships under climate change. Environmental Conservation 45(1): 20-29. Doi: 10.1017/S0376892917000169

The Scottish Government 2015. Towards a Social Enterprise Strategy 2016-2025. Documentation of a Conference on: Social Enterprise in Biosphere Reserves. Ayrshire, Scotland. Available at: http://social-capital.net/wpcontent/uploads/2017/10/151000-SEBR-International-Conference-Report-Oct-15-copy.pdf (accessed: 22/01/2021)

Speelman, E.N., J.C.J. Groot, L.E. García-Barrios, H. Van Keulen \& P. Tittonell 2014. From coping to adaptation to economic and institutional change Trajectories of change in land-use management and social organization in a Biosphere Reserve community, Mexico. Land Use Policy 41: 31-44.

Stoll-Kleemann, S. \& T. O’Riordan 2018. Biosphere Reserves in the Anthropocene. In: DellaSala, D.A. \& M.I. Goldstein (eds.), The Encyclopedia of the Anthropocene 3: 347-353. Oxford. Doi: 10.1016/B9780-12-809665-9.09828-1

Stoll-Kleemann, S. \& M. Welp 2008. Participatory and Integrated Management of Biosphere Reserves Lessons from Case Studies and a Global Survey. GALA 17: 161-168.

Taggart-Hodge, T.D. \& M. Schoon 2016. The challenges and opportunities of transboundary cooperation through the lens of the East Carpathians Biosphere Reserve. Ecology and Society 21(4): 29. Doi: 10.5751/ES-08669-210429

UNESCO 1996. Seville Strategy and the Statutory Framework of the WNBR 1995. Available at: http:// unesdoc.unesco.org/images/0010/001038/103849Eb. pdf (accessed: 05/10/2020)

UNESCO 2009. Madrid Action Plan 2008. Available at: http://unesdoc.unesco.org/ images/0016/001633/163301e.pdf (accessed:05/10/2020)

UNESCO 2015a. MAB STRATEGY 20152025. Available at: http://www.unesco.org/new/ fileadmin/MULTIMEDIA/HQ/SC/pdf/MAB_ Strategy_2015-2025_final_text.pdf (accessed: $05 / 10 / 2020)$

UNESCO 2015b. UNESCO Competency Framework. Learn. Develop. Excel. Available at: https://en.unesco. org/sites/default/files/competency_framework_e. pdf (accessed: 05/10/2020)
UNESCO 2016a. About the Man and the Biosphere Programme (MAB). Available at: http://www.unesco. org/new/en/naturalsciences/environment/ ecologicalsciences/man-and-biosphereprogramme/ about-mab/ (accessed: 05/10/2020)

UNESCO 2016b. Lima Action Plan 2016-2025. Available at: http://www.unesco.org/new/fileadmin/ MULTIMEDIA/HQ/SC/pdf/Lima_Action_Plan_ en_final_01.pdf (accessed: 05/10/2020)

United Nations 2015. Transforming our world: the 2030 Agenda for Sustainable Development. Resolution A/RES/70/1. Available at: http://www.un.org/ en/development/desa/population/migration/ generalassembly / docs / globalcompact / A_ RES_70_1_E.pdf (accessed: 05/10/2020)

von Lindern, E., R. Knoth-Letsch, V. Häring, C. Klenovec, M. Hunziker, A. Wallner \& F. Knaus 2020. Akzeptanz, Identifikation und Engagement: Ergebnisse und Implikationen aus einer Bevölkerungsumfrage in acht UNESCO Biosphere Reserves in der Schweiz, Deutschland und Österreich. In: Borsdorf, A., M. Jungmeier, V. Braun \& K. Heinrich (eds.), Biosphäre 4.0 - UNESCO Biosphere Reserves als Modellregionen einer nachbaltigen Entwicklung: 121-138.

Wallner, A. \& U. Wiesmann 2009. Critical issues in managing protected areas by multi-stakeholder participation - analysis of a process in the Swiss Alps. eco. mont - Journal on Protected Mountain Areas Research and Management 1(1): 45-50. Doi: 10.1553/eco.mont1s45

Wattendorf, P., W. Konold, C. Hertz-Kleptow, J. Schumacher \& J. Bihlmaier 2017. Untersuchung zur Umsetzung des Kernzonenkonzepts in deutschen Biosphärenreservaten und deren Inwertsetzung. BfN-Skripten 464. Bonn.

Weber, F. \& F. Weber 2020. Grenzen überwinden Herausforderungen und Potenziale bei der Weiterentwicklung des Biosphärenreservates Pfälzerwald-Nordvogesen. In: Borsdorf, A., M. Jungmeier, V. Braun \& K. Heinrich (eds.), Biosphäre 4.0 - UNESCO Biosphere Reserves als Modellregionen einer nachbaltigen Entwicklung: 227-238.

Weixlbaumer, N., T. Hammer, I. Mose \& D. Siegrist 2020. Das Biosphere Reserve-Konzept in Deutschland, Österreich und der Schweiz - Paradigmatische Entwicklung und zukünftige Herausforderungen im Spannungsfeld von Regionalentwicklung und globaler Nachhaltigkeit. In: Borsdorf, A., M. Jungmeier, V. Braun \& K. Heinrich (eds.), Biosphäre 4.0 UNESCO Biosphere Reserves als Modellregionen einer nachbaltigen Entwicklung: 99-120.

Zerbe, S., P. Annighöfer, I. Mölder, H. Schneider, A. Terwei \& C. Ammer 2020. Biosphere Reserves als Reallabore für ein nachhaltiges Management von nicht einheimischen Pflanzenarten. In: Borsdorf, A., M. Jungmeier, V. Braun \& K. Heinrich (eds.), Biosphäre 4.0 - UNESCO Biosphere Reserves als Modellregionen einer nachbaltigen Entwicklung: 239-254. 


\section{Authors}

\section{Michael Jungmeier}

is professor for nature conservation and sustainable development. His research focuses on planning and managing protected areas in the context of a changing society. UNESCO Chair for Sustainable Management of Conservation Areas, Carinthia University of Applied Sciences, Austria

\section{Axel Borsdorf}

is an emeritus professor of Geography at the University of Innsbruck and the former director of the Institute for Interdisciplinary Mountain Research of the Austrian Academy of Sciences. He has carried out research in mountainous regions continuously since 1971. Professor emeritus, Institute of Geography, University of Innsbruck, Austria

\section{Valerie Braun}

has a $\mathrm{PhD}$ in eco-physiology of alpine plants and is now co-editor of eco.mont. Institute for Interdisciplinary Mountain Research, Austrian Academy of Sciences, Austria

\section{Volker Häring}

studied geography and was a researcher for 8 years in interdisciplinary projects on the topic of sustainable land use. Since 2017, he has been working at the office of the Swabian Alb biosphere Reserve in the area of evaluation, research and monitoring. Schwäbische Alb UNESCO Biosphere Reserve, Germany

\section{Thomas Hammer}

is professor at the Centre for Development and Environment (CDE) and head of the study programm Sustainable Development at the CDE at the University of Bern, Switzerland.

\section{Christina Pichler-Koban}

ia senior scientist at E.C.O. Institute of Ecology. Her main focus of research is the analysis of the interaction between society and conservation, as well as the history and development of conservation paradigms from a historic and current perspective. Austria. Email: pichler-koban@e-c-o.at 